University of Nebraska - Lincoln

DigitalCommons@University of Nebraska - Lincoln

Nebraska Game and Parks Commission -- Staff

Research Publications

Nebraska Game and Parks Commission

January 1960

\title{
Pike Hybrids (Esox lucius x E. vermiculatus) in a Sandhill Lake, Nebraska
}

D. B. McCarraher

Nebraska Game, Forestation and Parks Commission, Bassett, Nebraska

Follow this and additional works at: https://digitalcommons.unl.edu/nebgamestaff

Part of the Environmental Sciences Commons

McCarraher, D. B., "Pike Hybrids (Esox lucius x E. vermiculatus) in a Sandhill Lake, Nebraska" (1960).

Nebraska Game and Parks Commission -- Staff Research Publications. 5.

https://digitalcommons.unl.edu/nebgamestaff/5

This Article is brought to you for free and open access by the Nebraska Game and Parks Commission at DigitalCommons@University of Nebraska - Lincoln. It has been accepted for inclusion in Nebraska Game and Parks Commission -- Staff Research Publications by an authorized administrator of DigitalCommons@University of Nebraska - Lincoln. 
Pike Hybrids (Esox lucius $x$ E. vermiculatus) in a Sandhill Lake, Nebraska ${ }^{1}$

In the sandhill region of Nebraska both northern pike, Esox lucius, and grass pickerel, Esox vermiculatus, are abundant in several shallow natural lakes. Both species are known to utilize the same vegetative habitat for spawning during March and April. The pike is an important game species but the smaller pickerel is of little value to fishermen although in winter is at times taken by angling through the ice.

Hybridization in the pike family, Esocidae, has been noted several times in the past. Underhill (1939) and Embody (1918) produced an artificial cross between the northern pike and chain pickerel, Esox lucius $\times E$. niger. Eddy (1941) reported on hybrids between northern pike and the muskellunge (E. masquinongy). Greeley (1939) observed a cross between the chain pickerel and redfin pickerel, E. niger $\times E$. americanus. Raney (1957) examined many hybrids of the niger $X$ americanus cross including back crosses. He found that in almost all instances the back crosses to a parent species were intermediate between the hybrid and the parent species. But it appears from a review of the available literature that a description of the lucius $\times$ vermiculatus cross has not been recorded.

${ }^{1} A$ contribution of Federal Aid to Fisheries, F-4-R, Job No. 2.

\section{EVIDENCE OF HYBRIDIZATION}

In several sandhill lakes the grass pickerel attains lengths up to 14.0 inches, although the average size of mature fish is probably around 8.0 inches. The pickerel has been found to mature and enter spawning grounds at 4.0 inches in length. Most male northern pike reach maturity at 18.0 inches in Nebraska and are directly associated with the pickerel during the spawning season. It is not unlikely, therefore, that hybridization could occur if the two species are genetically compatible.

The first probable lucius $\times$ vermiculatus hybrid found in Nebraska was taken during the ice-fishing season of 1958-59. It was caught on hook and line in Watts Lake, a 230-acre lake on the Valentine National Wildlife Refuge. During the ice-fishing season two other hybrids are known to have been caught from this same lake. Several other pike, also reported as "queer" looking, were taken by anglers but were not seen by state fishery biologists. The northern pike population in this lake is mostly of Age II and III fish since winter kill in 1955-56 nearly eliminated older fish.

Trammel and fyke netting on Watts Lake in the early spring of 1959 produced three additional hybrid fish. These fish were netted in conjunction with the northern pike spawntaking project at the lake. Spawning populations of both species appeared to be high at this time.

TABLE 1.-Characteristics of four hybrid pike (Esox lucius $\times$ E. vermiculatus) from Watts Lake, Nebraska

\begin{tabular}{|c|c|c|c|c|c|c|}
\hline \multirow{2}{*}{ Item } & \multicolumn{4}{|c|}{ Hybrid } & \multirow{2}{*}{ Northern pike } & \multirow[b]{2}{*}{ Grass pickerel } \\
\hline & Number 1 & Number 2 & Number 3 & Number 4 & & \\
\hline Total length (inches) & 18.8 & 19.2 & 20.0 & 18.2 & - & - \\
\hline $\begin{array}{l}\text { Weight (pounds) } \\
\text { Sex } \\
\text { Sensory pores } \\
\text { Subocular bar } \\
\text { Branchiostegals (one side) } \\
\text { Lateral line scales } \\
\text { Dorsal ray counts } \\
\text { Body markings } \\
\text { Cheeks } \\
\text { Opercle } \\
\text { Age } \\
\text { Gonad development } 1\end{array}$ & $\begin{array}{l}1.9 \\
\text { Female } \\
5 \\
\text { None } \\
12 \\
98 \\
15 \\
\text { Dark, oblique } \\
\text { bars } \\
\text { Fully scaled } \\
1 / 4 \text { scaled } \\
\text { II } \\
\text { Immature }\end{array}$ & $\begin{array}{l}2.0 \\
\text { Female } \\
4 \\
\text { None } \\
12 \\
16 \\
\text { Dark, oblique } \\
\text { bars } \\
\text { Fully scaled } \\
1 / 4 \text { scaled } \\
\text { II } \\
\text { Immature }\end{array}$ & $\begin{array}{l}2.2 \\
\text { Female } \\
4 \\
\text { None } \\
13 \\
120 \\
16 \\
\text { Dark, oblique } \\
\text { bars } \\
\text { Fully scaled } \\
1 / 4 \text { scaled } \\
\text { II } \\
\text { Immature }\end{array}$ & $\begin{array}{l}1.4 \\
\text { Female } \\
5 \\
\text { None } \\
14 \\
102 \\
15 \\
\text { Dark, oblique } \\
\text { bars } \\
\text { Fully scaled } \\
1 / 2 \text { scaled } \\
\text { II }\end{array}$ & \multirow[t]{2}{*}{$\begin{array}{l}5 \\
\text { None } \\
14-16 \\
120-125 \\
14-16 \\
\text { Light spots } \\
\text { Fully scaled } \\
1 / 2 \text { scaled } \\
\quad-\end{array}$} & \multirow[t]{2}{*}{$\begin{array}{l}4 \\
\text { Present } \\
11-13 \\
90-110 \\
17-18 \\
\text { Dark, oblique } \\
\text { bars } \\
\text { Fully scaled } \\
\text { Fully scaled } \\
\qquad-\end{array}$} \\
\hline f eye to po & Jaw to cent & 1 & & & & \\
\hline
\end{tabular}

1Histological examinations were not made.

Reprinted from Transactions American Fisheries Society Volume 89 (1) 1960. Printed in USA. 


\section{DESCRIPTION OF HYBRID PIKE}

Coloration and marking of the Nebraska hybrids resembles closely that of grass pickerel. Alternating dark and light bars extend obliquely forward and ventrally to the lateral margin of the belly. The bars are irregular with slight fuzzing or blotching along the dorsal body surface in two of the specimens. Body color is generally dark. Other characteristics of the Watts Lake hybrids are listed in Table 1.

\section{LITERATURE CITED}

Eddy, Samuel. 194l. Muskellunge and muskie hybrids. Minnesota Cons. Vol., 3(14) : 41-44.
EмвоDY, G. C. 1918. Artificial hybrids between pike and pickerel. Jour. Hered., 9: 253-256.

GrEeley, J. R. 1939. II. The fresh-water fishes of Long Island and Staten Island with annotated list. In: A biological survey of the fresh waters of Long Island. N. Y. Cons. Dept., Biol. Surv. (1938), 13: 29-44.

Raney, Edward C. 1957. Natural hybrids between two species of pickerel (Esox) in Stearns Pond, Massachusetts. Suppl. to Fisheries Report for some central, eastern, and western Massachusetts lake, ponds, and reservoirs, 1951-52, Mass. Div. Fish. and Game, $15 \mathrm{pp}$.

Underhili, A. Heaton. 1939. Cross between Esox niger and Esox lucius. Copeia, 1939(4) : 237.

\section{Nebraska Game, Forestation and Parks}

D. B. McCarraher

Commission

Bassett, Nebraska 